\title{
UWARUNKOWANIA POTRZEB ZDROWOTNYCH REALIZOWANYCH PRZEZ AKTYWNOŚĆ FIZYCZNĄ OSÓB STARSZYCH
}

\section{DETERMINANTS OF HEALTH NEEDS IN THE ELDERLY REALIZED THROUGH PHYSICAL ACTIVITY}

\author{
Zofia Kubińska ${ }^{1(\mathrm{~A}, \mathrm{~B}, \mathrm{E}, \mathrm{F})}$, Anna Pańczuk ${ }^{1(\mathrm{C}, \mathrm{D}, \mathrm{E}, \mathrm{F})}$
}

${ }^{1}$ Zakład Fizjoterapii, Katedra Kultury Fizycznej i Fizjoterapii, Państwowa Szkoła Wyższa im. Papieża Jana Pawła II w Białej Podlaskiej

\begin{abstract}
Kubińska, Z., Pańczuk, A. (2019). Uwarunkowania potrzeb zdrowotnych realizowanych przez aktywność fizyczną osób starszych. Rozprawy Społeczne, 13(1), 57-63. https://doi.org/10.29316/rs.2019.07
\end{abstract}

Wkład autorów:

A. Zaplanowanie badań

B. Zebranie danych

C. Dane - analiza i statystyki

D. Interpretacja danych

E. Przygotowanie artykułu

F. Wyszukiwanie i analiza

literatury

G. Zebranie funduszy

\begin{abstract}
Streszczenie
Celem pracy było poszukiwanie zależności pomiędzy uwarunkowaniami (płcią, miejscem zamieszkania, wykształceniem, wiekiem, samooceną stanu zdrowia, uczestnictwem w aktywności fizycznej oraz intensywnością wysiłku fizycznego w ramach wykonywanego zawodu), a potrzebami zdrowotnymi realizowanymi przez aktywność fizyczną. Materiał i metoda. Badania przeprowadzono w 2016 roku wśród 221 mieszkańców powiatu bialskiego i okolic w wieku 60-90 lat. W pracy zastosowano sondaż diagnostyczny z autorskim kwestionariuszem ankiety, w którym badani oceniali stopnie realizacji jedenastu potrzeb zdrowotnych poprzez podejmowaną obecnie aktywność fizyczną. Wyniki. Nie wykazano istotnego zróżnicowania stopnia realizacji potrzeb zdrowotnych względem płci oraz miejsca zamieszkania. Wykazano istotne zróżnicowanie względem wykształcenia a stopniem realizacji potrzeby aktywnej niepełnosprawności oraz rekreacji ruchowej; wiekiem a realizacją potrzeby profilaktycznej; samooceną stanu zdrowia a realizacją potrzeby prorodzinnej, profilaktycznej, ruchu, aktywności turystycznej, rekreacji ruchowej, medycznej i rehabilitacji; dotychczasowym uczestnictwem w aktywności fizycznej a potrzebą ruchu, antyinwolucyjną oraz profilaktyczną; intensywnością wysiłku fizycznego w ramach wykonywanego zawodu a potrzeba prorodzinna, aktywnej niepełnosprawności, rekreacji ruchowej oraz funkcjonalno-czynnościowej. Wnioski. Do uwarunkowań, które różnicują potrzeby zdrowotne realizowane przez aktywność fizyczną badanych seniorów należą: wykształcenie, wiek, stan zdrowia, wcześniejsze uczestnictwo w aktywności fizycznej oraz rodzaj wykonywanego zawodu pod względem intensywności wysiłku fizycznego. W żadnej z analizowanych potrzeb nie wykazano istotnego zróżnicowania w zależności od płci oraz miejsca zamieszkania badanych seniorów.
\end{abstract}

Słowa kluczowe: osoby starsze, potrzeby zdrowotne, aktywność fizyczna

\section{Summary}

Introduction and objective. The aim of the present paper is showing an interdependence between the determining factors (sex, place of residence, education, age, self-esteem of the health status, participation in physical activities and intensity of a physical effort connected with performing professional duties) and health needs of elderly people, realized by through physical activities. Material and method. The research was conducted in 221 people aged 60-90 years. A diagnostic survey was used as the research method. It consisted of the author's questionnaire in which the respondents were asked to evaluate the degree of realization of eleven health needs through the currently undertaken physical activities. Results. No significant variation of the degree of realization of health needs with regards to sex and place of living was found. However, there were significant variations due to such factors as education and the degree of realization of one's active disability needs and motor recreation; age and realization of the preventive need; the self-estimation of one's health state and realization of a pro-family, preventive, mobility, tourist activity, motor and medical recreation, and a rehabilitation need; previous participation in physical activities and the need of mobility, anti-involution and prevention; intensity of a physical effort within professional duties and a pro-family, active disability, motor and functional recreation need. Conclusions. Among the determinants diversifying health needs of the tested seniors realized through their physical activities, one may include education, age, health state, previous participation in physical activities, as well as the occupation the intensity of effort it involves. Within none of the analyzed needs, there was found a significant variation with regard to the respondents' sex or place of living.

Keywords: the elderly, health needs, physical activity 


\section{Wprowadzenie}

Starzenie się jest okresem nieuchronnych zmian regresyjnych i destrukcyjnych, które mają indywidualny przebieg. Jest to okres nowych i trudnych życiowo sytuacji, które wymagają wielu adaptacyjnych zachowań (Okła, 2006). Do najważniejszych, negatywnych zmian w życiu osób starszych należą: osłabienie sprawności fizycznej i psychicznej, wydolności i siły fizycznej, zaburzenia równowagi, koordynacji ruchowej, upadki, częstsze odczuwanie zmęczenia, ociężałości i niechęci do aktywnych wysiłków fizycznych. Następuje ubytek masy mięśniowej (sarkopenia) i ubytek masy kostnej (Kostka, 2010; Cruz-Jentoft i in., 2010). Jednocześnie tym zmianom towarzyszą nowe sytuacje psychospołeczne, pogarszające stan jakości życia, takie jak: wyłączenie z życia zawodowego, społecznego, towarzyskiego, rodzinnego, odejście najbliższych, pogorszenie sytuacji materialnej, zmiana ról, utrata poczucia wartości (atrakcyjności). Pogarsza się codzienne funkcjonowanie, pojawiają się dolegliwości, bezsenność, bóle głowy, stawów, kręgosłupa, choroby, niepełnosprawność, czyli utrata zdrowia i sprawności (Bień, 2002; Marchewka, Dąbrowski, Żołądź, 2013; Chipperfield, 2008). W związku z powyższym, w życiu osób starszych pojawiają się nowe wyzwania, czyli radzenie sobie $\mathrm{z}$ trudami, akceptacja niekorzystnych zmian i umiejętność adaptacji do starości (Kryszkiewicz, 2006; Nowak, Rynkiewicz, Umiastowska, 2009).

Jednym z głównych czynników, który w znaczący i sprawdzony sposób korzystnie wpływa na jakość procesu starzenia się i przystosowania się do starości jest systematyczna, umiarkowana aktywność fizyczna. Według Osińskiego (2013), dzięki niej możliwe jest opóźnienie procesów starzenia się nawet o 10-20 lat. Ćwiczenia fizyczne opóźniają rozwój chorób układu krążenia, obniżają poziom ciśnienia tętniczego krwi, zwiększają objętość wyrzutową serca, uelastyczniają tętnice, zmniejszają ryzyko zachorowania na cukrzycę i miażdżycę (Kaźmierczak i in., 2015; MacAuley, 2001; Lampinen, Heikkinen, Kauppinen, Heikkinen, 2006). Zdaniem Mazurek i wsp. (2014) aktywność fizyczna stanowi postępowanie pierwszego rzutu, które zapobiega gwałtownie narastającym chorobom przewlekłym. Można ją również traktować jako podstawową metodę leczniczą pozwalającą ograniczyć stosowanie innych, bardziej kosztownych metod terapii. Polepszenie codziennego funkcjonowania osób starszych to nie tylko zadanie dla gerontologów, ale również interdyscyplinarny problem badawczy uwzględniający korzystny wpływ aktywności fizycznej na zdrowie i sprawność osób starszych (Kostka, 2003; Burke i in., 2010).

Ponieważ umiarkowana aktywność fizyczna seniorów, uprawiana w przeszłości i obecnie, sprzyja potęgowaniu zdrowia, należy ją uznać za potrzebę zdrowotną. Potrzeba zdaniem Gordon i wsp. (Gordon, Carter, Scott, 1997) istnieje wówczas, gdy jednostka nie ma tego co posiadają inne jednostki, w tym samym wieku i podobnej sytuacji. Według Światowej Organizacji Zdrowia (WHO) potrzeby zdrowotne sa to „zakłócenia w stanie zdrowia lub samopoczuciu społecznym, które wymagają interwencji w postaci działań leczniczych, rehabilitacyjnych lub pomocy społecznej, a także działań zapobiegawczych" (za Topór-Mądry, Gilis-Januszewska, Kurkiewicz, Pająk, 2002, s. 15).

\section{Cel pracy}

Celem pracy było poszukiwanie zależności pomiędzy uwarunkowaniami (płcią, miejscem zamieszkania, wykształceniem, wiekiem, samooceną stanu zdrowia, uczestnictwem w aktywności fizycznej oraz intensywnością wysiłku fizycznego w ramach wykonywanego zawodu), a potrzebami zdrowotnymi realizowanymi przez aktywność fizyczną.

\section{Materiały i metoda}

Badania przeprowadzono w 2016 roku wśród osób starszych zamieszkałych w powiecie bialskim i okolicach (północna część województwa lubelskiego). Przebadano 221 osób w wieku 60-90 lat (średnia 69,9). W badaniach sondażowych wykorzystano autorski kwestionariusz ankiety. Zawierał on metryczkę oraz pytania zamknięte dotyczące samooceny obecnego stanu zdrowia, dotychczasowego uczestnictwa w aktywności fizycznej, charakterystyki wykonywanego zawodu pod względem intensywności wysiłku fizycznego. Charakterystykę badanych zamieszczono w tabeli 1 .

Tabela 1. Charakterystyka badanej grupy

\begin{tabular}{|c|c|c|}
\hline \multirow{2}{*}{ Płeć } & kobieta & $65,6 \%$ \\
\cline { 2 - 3 } & mężczyzna & $34,4 \%$ \\
\hline \multirow{4}{*}{ Miejsce zamieszkania } & miasto & $43,1 \%$ \\
\cline { 2 - 3 } Wykształcenie & wieś & $56,9 \%$ \\
\cline { 2 - 3 } & podstawowe & $20,2 \%$ \\
\cline { 2 - 3 } & zawodowe & $40,8 \%$ \\
\cline { 2 - 3 } & średnie & $28,4 \%$ \\
\hline \multirow{3}{*}{$\begin{array}{c}\text { Samoocena stanu } \\
\text { zdrowia }\end{array}$} & wyższe & $10,6 \%$ \\
\cline { 2 - 3 } & bardzo dobry & $8,2 \%$ \\
\cline { 2 - 3 } & dobry & $60,0 \%$ \\
\cline { 2 - 3 } & słaby & $26,8 \%$ \\
\hline \multirow{3}{*}{$\begin{array}{c}\text { Dotychczasowe } \\
\text { uczestnictwo } \\
\text { w aktywności fizycznej }\end{array}$} & bardzo słaby & $5,0 \%$ \\
\cline { 2 - 3 } & systematyczne & $30,9 \%$ \\
\hline \multirow{2}{*}{$\begin{array}{c}\text { Zawód wymagający } \\
\text { wysiłku fizycznego }\end{array}$} & sporadyczne & $45,9 \%$ \\
\cline { 2 - 3 } & minimalne & $23,2 \%$ \\
\cline { 2 - 3 } & intensywnego & $30,2 \%$ \\
\hline \multirow{2}{*}{$\begin{array}{c}\text { umiarkowanego } \\
\text { Zinimalnego }\end{array}$} & $40,9 \%$ \\
\hline
\end{tabular}

Źródło: Opracowanie własne

W zastosowanym kwestionariuszu ankiety ba- 
dani oceniali również stopnie realizacji jedenastu potrzeb zdrowotnych poprzez podejmowaną obecnie aktywność fizyczną. Uwzględnione w analizie potrzeby zdrowotne wyszczególniono na podstawie literatury przedmiotu (Kubińska, Pańczuk, 2018), a ich ogólną charakterystykę zamieszczono w tabeli 2 . również najwyższe wartości średnie wśród osób z wykształceniem podstawowym, zawodowym oraz średnim. Inną kolejność zaobserwowano w grupie z wykształceniem wyższym, w której dominowała potrzeba ruchu i profilaktyczna, a prorodzinna uplasowała się dopiero na szóstym miejscu. Wśród osób oceniających swój stan zdrowia

Tabela 2. Rodzaje potrzeb zdrowotnych zaspokajanych przez aktywność fizyczną (opracowanie własne na podstawie literatury) (Kubińska, Pańczuk, 2018)

\begin{tabular}{|l|l|}
\hline \multicolumn{1}{|c|}{ Potrzeby zdrowotne } & \multicolumn{1}{c|}{ Opis } \\
\hline $\begin{array}{l}\text { Potrzeba aktywności tury- } \\
\text { stycznej }\end{array}$ & $\begin{array}{l}\text { AF umożliwiająca kontakt z otoczeniem przyrodniczym, kulturowym, budująca zasoby } \\
\text { odpornościowe i poznawcze. Potrzeba podejmowana i realizowana dobrowolnie. }\end{array}$ \\
\hline $\begin{array}{l}\text { Potrzeba aktywnej niepeł- } \\
\text { nosprawności }\end{array}$ & $\begin{array}{l}\text { AF osób z niepełnosprawnością, zwiększająca samodzielność i aktywność społeczną. Zale- } \\
\text { cana przez lekarza, realizowana przez fizjoterapeutę, rodzinę, opiekuna. }\end{array}$ \\
\hline Potrzeba antyinwolucyjna & $\begin{array}{l}\text { AF opóźniająca procesy starzenia, spadek wydolności, sprawności fizycznej, deficyty biolo- } \\
\text { giczne, psychiczne i społeczne. Podejmowana dobrowolnie. }\end{array}$ \\
\hline $\begin{array}{l}\text { Potrzeba funkcjonalno } \\
\text {-czynnościowa }\end{array}$ & $\begin{array}{l}\text { AF po chorobie, urazie, operacji, przywracająca umiejętność lokomocji, samodzielnego } \\
\text { funkcjonowania. Zalecana przez lekarza, fizjoterapeutę. }\end{array}$ \\
\hline Potrzeba medyczna & AF zalecana przez lekarza w chorobie lub rekonwalescencji. \\
\hline Potrzeba profilaktyczna & $\begin{array}{l}\text { AF zapobiegająca (minimalizująca) schorzeniom, chorobom, niepełnosprawności. Podejmo- } \\
\text { wana samodzielnie, dobrowolnie. }\end{array}$ \\
\hline Potrzeba prorodzinna & $\begin{array}{l}\text { AF umożliwiająca kontakty, relacje rodzinne, wspólne świętowanie, aktywność wolnocza- } \\
\text { sową, zabawy ruchowe z wnukami, dziećmi, mężem, żoną, prace fizyczne. Potrzeba realizo- } \\
\text { wana dobrowolnie. }\end{array}$ \\
\hline Potrzeba rehabilitacyjna & $\begin{array}{l}\text { AF zalecana przez lekarza, przywracająca utracone (po chorobie, wypadku) funkcje. Reali- } \\
\text { zowana przez fizjoterapeutę, rehabilitanta, masażystę. }\end{array}$ \\
\hline $\begin{array}{l}\text { Potrzeba rekreacji rucho- } \\
\text { wej }\end{array}$ & $\begin{array}{l}\text { AF wolnoczasowa i dobrowolna umożliwiająca regenerację, relaksację po zmęczeniu fizycz- } \\
\text { nym, psychicznym, społecznym, dostarczająca przyjemnch wrażeń, poprawiająca spraw- } \\
\text { ność. }\end{array}$ \\
\hline Potrzeba rewitalizacji & $\begin{array}{l}\text { AF zwiększająca żywotność ustroju, witalność organizmu, usprawniająca procesy życiowe } \\
\text { (fizyczne, umysłowe, emocjonalne), dodająca życia do lat. Podejmowana samodzielnie. }\end{array}$ \\
\hline Potrzeba ruchu & $\begin{array}{l}\text { AF w samodzielnym, świadomym praktykowaniu zdrowego stylu życia, oparta na wiedzy } \\
\text { i doświadczeniach, dająca poczucie wartości i dbałości o zdrowie. }\end{array}$ \\
\hline
\end{tabular}

AF - aktywność fizyczna

Źródło: Opracowanie własne

Stopniom realizacji poszczególnych potrzeb zdrowotnych przyporządkowane były wartości liczbowe $(0$ - brak potrzeby, 1 - w minimalnym stopniu, 2 - w dość dużym stopniu, 3 - w dużym stopniu, 4 - w największym stopniu), przy czym 4 (w największym stopniu) można było wybrać tylko raz. Skala ilościowa umożliwiła przedstawienie wyników w postaci średnich arytmetycznych i zastosowanie testu Manna-Whitneya w przypadku cech przyjmujących dwie wartości oraz testu Kruskalla-Wallisa z testem post-hoc przy więcej niż dwóch wartościach cechy. Analizę statystyczną przeprowadzono z wykorzystaniem oprogramowania komputerowego Statistica v. 10.0 (StatSoft, Polska), a w zastosowanych testach za poziom istotności przyjęto $\mathrm{p}<0,05$.

\section{Wyniki}

Analiza stopnia realizacji poszczególnych potrzeb zdrowotnych wykazała, iż potrzeba prorodzinna dominowała niezależnie od płci, miejsca zamieszkania oraz wieku badanych. Uzyskała ona jako bardzo dobry największe wartości średnie uzyskano w odniesieniu do potrzeby ruchu. Z kolei potrzeba prorodzinna i profilaktyczna uzyskały największe wartości średnie w grupie osób oceniających stan zdrowia jako dobry oraz słaby. Wśród osób o bardzo słabym stanie zdrowia największe wartości uzyskały potrzeba funkcjonalno-czynnościowa oraz rewitalizacji. Dominację potrzeby prorodzinnej zaobserwowano również w grupie osób o sporadycznym i minimalnym uczestnictwie w aktywności fizycznej, natomiast wśród deklarujących systematyczne uczestnictwo w aktywności fizycznej największą wartość średnią uzyskano w odniesieniu do potrzeby ruchu, a prorodzinna uplasowała się na drugim miejscu. Potrzeba prorodzinna dominowała również wśród osób, które wykonywały zawód wymagający intensywnego lub umiarkowanego wysiłku fizycznego. Z kolei wśród respondentów wykonujących $\mathrm{w}$ przeszłości zawód wymagający minimalnego wysiłku fizycznego dominowały potrzeba profilaktyczna, w dalszej kolejności ruchu i prorodzinna (tabela 3). 
Tabela 3. Stopnie realizacji potrzeb zdrowotnych przez aktywność fizyczną w zależności od uwarunkowań (dane w postaci średnich arytmetycznych)

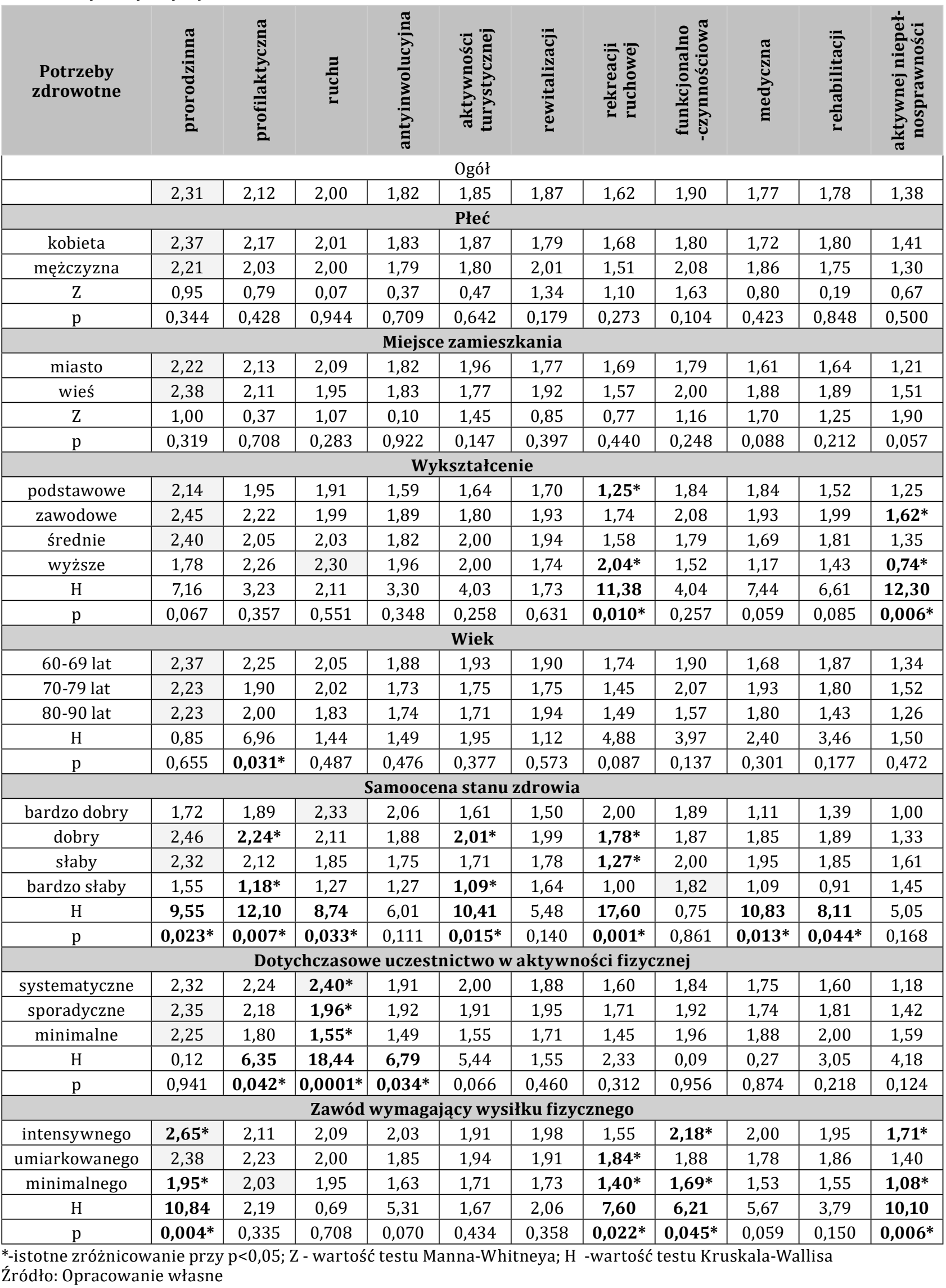


Analiza stopnia realizacji potrzeb zdrowotnych nie wykazała istotnego zróżnicowania w zależności od płci oraz miejsca zamieszkania badanych seniorów. Uwzględniając wiek badanych, zaobserwowano istotną zależność w odniesieniu do potrzeby profilaktycznej, jednakże szczegółowa analiza nie wykazała pomiędzy którymi grupami wiekowymi zachodzi to zróżnicowanie. Wśród uwzględnionych grup, istotne zróżnicowanie zaobserwowano w odniesieniu do wykształcenia, samooceny stanu zdrowia, wcześniejszego uczestnictwa w aktywności fizycznej oraz rodzaju wykonywanego zawodu pod względem intensywności wysiłku fizycznego (tabela 3).

Osoby z wykształceniem zawodowym w istotnie większym stopniu, aniżeli z wykształceniem wyższym, realizują potrzebę aktywnej niepełnosprawności, z kolei osoby z wyższym wykształceniem $\mathrm{w}$ istotnie większym stopniu, aniżeli $\mathrm{z}$ podstawowym, realizują potrzebę rekreacji ruchowej.

Analiza uwzględniająca samoocenę stanu zdrowia badanych wykazała, iż w odniesieniu do potrzeby rekreacji ruchowej, ruchu oraz rehabilitacji uzyskiwano większe wartości średnie wraz ze wzrostem samooceny stanu zdrowia. W zakresie potrzeby rekreacji ruchowej $\mathrm{w}$ istotnie większym stopniu realizują ją osoby z dobrym stanem zdrowia, aniżeli słabym. Z kolei potrzebę profilaktyczną oraz aktywności turystycznej, w istotnie większym stopniu realizują osoby z dobrym stanem zdrowia, aniżeli bardzo słabym.

Uwzględniając dotychczasowe uczestnictwo badanych w aktywności fizycznej, potrzeba ruchu uzyskała istotnie większe średnie wśród osób o systematycznej aktywności fizycznej, aniżeli sporadycznej oraz minimalnej.

Analiza uwzględniająca intensywność wysił$\mathrm{ku}$ fizycznego w ramach wykonywanego zawodu wykazała, iż potrzebę prorodzinną, aktywnej niepełnosprawności oraz funkcjonalno-czynnościową w istotnie większym stopniu deklarowały osoby, które wykonywały zawód wymagający intensywnego wysiłku fizycznego, aniżeli minimalnego. Z kolei potrzebę rekreacji ruchowej w istotnie większym stopniu deklarowały osoby, które wykonywały zawód wymagający umiarkowanego wysiłku fizycznego, aniżeli minimalnego.

\section{Dyskusja}

W badaniach potrzeb zdrowotnych seniorów, realizowanych przez podejmowaną aktywność fizyczną, w największym stopniu oraz najczęściej realizowana była potrzeba prorodzinna, a w dalszej kolejności profilaktyczna i ruchu (Kubińska, Pańczuk, 2018). Przeprowadzona w artykule analiza wykazała dominację potrzeby prorodzinnej niezależnie od płci, miejsca zamieszkania oraz wieku badanych. Dominowała ona również wśród osób z wykształceniem podstawowym, zawodowym oraz średnim; w grupie osób o sporadycznym i minimalnym uczestnictwie w aktywności fizycznej; wśród osób, które wykonywały zawód wymagający intensywnego lub umiarkowanego wysiłku fizycznego oraz w grupie oceniającej stan swojego zdrowia jako dobry oraz słaby. Emeryci badani przez Koprowiak i Nowak, w większości przeznaczają czas wolny na pomoc w codziennych obowiązkach dzieciom i wnukom, na uprawianie działki, oglądanie telewizji, słuchanie radia, czy tanie książek (Koprowiak, Nowak, 2007). Według badań Bień, brak aktywności może przyczyniać się do samotności, izolacji społecznej, postępującej niesprawności, a nawet przedwczesnej umieralności (Bień, 2007).

W odniesieniu do analizowanych potrzeb zdrowotnych bialskich seniorów nie zaobserwowano istotnego statystycznie zróżnicowania w zależności od miejsca zamieszkania oraz płci. W badaniach Kantanista i wsp. (2013) oraz Łysak i wsp. (Łysak, Walentukiewicz, Drabik, Dąbrowski, Rowiński, 2014), więcej mężczyzn niż kobiet z Wielkopolski i województwa pomorskiego podejmowało różne formy aktywności fizycznej i czynili to częściej niż kobiety.

Analiza statystyczna realizowanych potrzeb uwarunkowanych wiekiem, wykazała istotną zależność jedynie w odniesieniu do potrzeby profilaktycznej. Badania wskazują, że wiek seniorów różnicuje zaangażowanie w aktywność fizyczną. Badani z Wielkopolski w wieku 64-74 lata (w porównaniu z kategorią wiekową 75-84 lub >85 lat) byli najaktywniejszą grupą, a w grupach wiekowych 85 lat i więcej, ani jeden badany nie podejmował aktywności fizycznej (Kantanista i in., 2013).

Dominująca w badaniu potrzeba prorodzinna wśród osób z wykształceniem wyższym uplasowała się dopiero na szóstym miejscu. W grupie tej, przez aktywność fizyczną, w największym stopniu realizowano potrzebę ruchu. Osoby z wykształceniem wyższym, $w$ istotnie większym stopniu niż z wykształceniem podstawowym, realizowały również potrzebę rekreacji ruchowej. Zdaniem Błędowskiego (2012), wzrastający systematycznie poziom wykształcenia w Polsce, któremu sprzyja polityka kształcenia przez całe życie, znajduje odzwierciedlenie w zmieniającym się stylu życia seniorów. Starsza generacja jest coraz bardziej świadoma swoich zadań w zakresie dbałości o zdrowie i zachowanie sprawności. Umiarkowana aktywność fizyczna seniorów, uprawiana w przeszłości i obecnie, sprzyja potęgowaniu zdrowia. Osoby uczestniczące w zajęciach UTW w Łodzi w ponad połowie przypadków podejmują aktywność fizyczną kilka razy w tygodniu. Prawie jedna trzecia badanych ćwiczy codziennie. W badaniach Umiastowskiej, częstotliwość podejmowania aktywności ruchowej przez słuchaczki Uniwersytetu Trzeciego Wieku w Stargardzie Szczecińskim i Myśliborzu jest podobna, prawie połowa ćwiczy kilka razy w tygodniu. Wyraźnie niższy jest natomiast odsetek aktywnych ruchowo codziennie, tylko 11\% studentów UTW z Myśliborza i nieco ponad 3\% ze Stargardu Szczecińskiego (Umiastowska, 2012). 
Bardzo dobry stan zdrowia badanych seniorów w największym stopniu warunkował potrzebę ruchu, antyinwolucyjną i rekreacji ruchowej. Natomiast bardzo słaby stan zdrowia związany był $\mathrm{z}$ wartościowaniem potrzeby funkcjonalno-czynnościowej i rewitalizacji. W badaniach Łysak i wsp. (2014), zły stan zdrowia wiązał się z brakiem potrzeby ruchu. Wcześniejsze i obecne uczestnictwo w aktywności fizycznej badanych wiązało się z wartościowaniem potrzeby ruchu, natomiast sporadyczne i minimalne z potrzebą prorodzinną, czyli budowaniem i utrzymaniem kapitału rodzinnego. Badania seniorów pomorskich ujawniły istotnie statystycznie różnice $\mathrm{w}$ podejmowaniu aktywności fizycznej przez osoby, które wyrobiły w sobie nawyk czyli „ćwiczyły w młodości” - było to zjawisko częściej występujące wśród mężczyzn (Łysak i in., 2014). W badaniach seniorów z województwa łódzkiego większość $(62,7 \%)$ nie zwracała uwagi na zdrowy tryb życia, a 35,7\% w przeszłości spędzało czas w sposób średnio aktywny. Ma to przełożenie na obecne podejście osób starszych do aktywności ruchowej. Jedynie $28,6 \%$ seniorów odczuwa potrzebę podejmowania aktywności ruchowej, 45,2\% odczuwa taką potrzebę w niewielkim stopniu, a 26,2\% nie odczuwa takiej potrzeby w ogóle. Głównym powodem nie podejmowania aktywności ruchowej przez osoby starsze w województwie łódzkim jest niestety stan zdrowia, prawie $40 \%$ badanych korzysta z usług poradni rehabilitacyjnej (Gosik, 2015).

Wykonywany zawód, pod względem intensywności wysiłku fizycznego, różnicował wśród badanych seniorów realizację potrzeby prorodzinnej, aktywnej niepełnosprawności, funkcjonalno-czynnościowej oraz rekreacji ruchowej. Pierwsze trzy potrzeby w istotnie większym stopniu deklarowały osoby, które wykonywały zawód wymagający intensywnego wysiłku fizycznego, aniżeli minimalnego. Z kolei potrzebę rekreacji ruchowej w istotnie większym stopniu deklarowali wykonujący zawód o umiarkowanym aniżeli minimalnym wysiłku fizycznym.

\section{Wnioski}

Spośród analizowanych potrzeb zdrowotnych w największym stopniu realizowana była potrzeba prorodzinna, która dominowała niezależnie od płci, miejsca zamieszkania oraz wieku badanych. Do uwarunkowań, które różnicują potrzeby zdrowotne realizowane przez aktywność fizyczną badanych seniorów należą: wykształcenie, wiek, stan zdrowia, wcześniejsze uczestnictwo w aktywności fizycznej oraz rodzaj wykonywanego zawodu pod względem intensywności wysiłku fizycznego. W żadnej $\mathrm{z}$ analizowanych potrzeb nie wykazano istotnego zróżnicowania w zależności od płci oraz miejsca zamieszkania badanych seniorów.

\section{Podziękowania}

Autorki składają podziękowania Adamowi Szepelukowi z Centrum Badań nad Innowacjami Państwowej Szkoły Wyższej w Białej Podlaskiej, za wykonanie obliczeń statystycznych wykorzystanych w artykule.

\section{Literatura:}

1. Bień, B. (2002). Stan zdrowia i sprawność ludzi starszych. W: B. Synak (red.), Polska starość (s. 35-77). Gdańsk: Wyd. Uniwersytetu Gdańskiego.

2. Bień, B. (2007). Proces starzenia się człowieka. W: T. Grodzicki, J. Kocemba, A. Skalska (red.), Geriatria z elementami gerontologii ogólnej (s. 42-46). Gdańsk: Via Medica.

3. Błędowski, P. (2012). Starzenie się jako problem społeczny. Perspektywa demograficznego starzenia się ludności Polski do roku 2035. W: M. Mossakowska, A. Więcek, P. Błędowski (red.), PolSenior Aspekty medyczne, psychologiczne, socjologiczne i ekonomiczne starzenia się ludzi w Polsce (s. 11-23). Poznań: Wyd. Termedia. Pobrane z: http://212.87.21.2/polsenior/sites/polsenior.iimcb.gov.pl/files/file/monografia/monografiaPolSenior.pdf

4. Burke, I., Jancey, J., Howat, P., Lee, A., Kerr, D., Shilton, T., Hills, A., Anderson, A. Physical activity and nutrition program for senior (PANS): protocol of a randomized controlled trial. BMC Publ Health, 10(1), 751. https://doi.org/10.1186/1471-2458-10-751

5. Chipperfield, J.G. (2008). Everyday physical activity as a predictor of late-life morality. Gerontologist, 48(3), 349-357. https://doi.org/10.1093/geront/48.3.349

6. Cruz-Jentoft, A.J., Baeyens, J.P., Bauer, J.M., Boirie, Y., Cederholm, T., Landi, F., Martin, F.C., Michel, J.P., Rolland, Y., Schneider, S.M., Topinková, E., Vandewoude, M., Zamboni, M. (2010). Sarcopenia: Europen consensus on definition and diagnosis: Report of the European Working Group on Sarcopenia In Older People. Age Ageing, 39(4), 412-423. https://doi.org/10.1093/ageing/afq034

7. Gordon, D.S., Carter, H., Scott, S. (1997). Profiling the care needs of the population with dementia: a survey in central Scotland. Int J Geriatr Psychiatry., 12(7), 753-759. https://doi.org/10.1002/(SICI)1099-1166(199707)12:7<753::AID-GPS629>3.0.C0;2-9

8. Gosik, B. (2015). Rekreacja i aktywność ruchowa starszych osób. Przykład mieszkańców województwa łódzkiego. W: A. Janiszewska (red.), Jakość życia ludzi starych - wybrane problemy (s. 155-163). Łódź: Uniwersytet Łódzki. 
9. Kantanista, A., Król-Zielińska, M., Szeklicki, R., Dąbrowski, A., Rowiński, R., Osiński, W. (2013). Aktywność fizyczna osób starszych z Wielkopolski w świetle ogólnopolskich badań PolSenior. Gerontologia Polska, 21(4), 113-118.

10. Kaźmierczak, U., Radzimińska, A., Dzierżanowski, M., Bułatowicz, I., Srtojek, K., Żukow, W. (2015). Korzyści z podejmowania regularnej aktywności fizycznej przez osoby starsze. Journal of Education, Health and Sport, 5(1), 56-68. http://dx.doi.org/10.5281/zenodo.13935

11. Koprowiak, E., Nowak, B. (2007). Style życia ludzi starszych. Annales Universitatis Mariae Curie-Skłodowska. Section D. Medicina, 62(Suppl.3), 372-375.

12. Kostka, T. (2003). Programowanie aktywności ruchowej u osób starszych. Medicina Sportiva, 57(Suppl. 1), 37-44.

13. Kostka, T. (2010). Aktywność fizyczna u osób w podeszłym wieku. W: P. Podolec (red.), Podręcznik Polskiego Forum Profilaktyki. T.2 (s. 455-460). Kraków: Wyd. Medycyna Praktyczna.

14. Kryszkiewicz, Cz. (2006). Aktywne życie seniorów warunkiem pomyślnego starzenia się. W: S. Steuden, M. Marczuk (red.), Starzenie się a satysfakcja z życia (s. 281-288). Lublin: Wydawnictwo KUL.

15. Kubińska, Z., Pańczuk, A. (2018). Potrzeby zdrowotne realizowane przez aktywność fizyczną osób starszych. Rozprawy Społeczne, 12(1), 73-79. https://doi.org/10.29316/rs.2018.09

16. Lampinen, P., Heikkinen, R.L., Kauppinen, M., Heikkinen, E. (2006). Activity as a predictor of mental well-being among older adults. Aging Ment Health, 10(5), 454-466. https://doi. org/10.1080/13607860600640962

17. Łysak, A., Walentukiewicz, A., Drabik, J., Dąbrowski, A., Rowiński, R. (2014). Aktywność fizyczna i niektóre jej uwarunkowania w populacji seniorów województwa pomorskiego. Hygeia Public Health, 49(3), 549-553.

18. MacAuley, D. (2001). The potential benefits of physical activity in older people. Med. Sportiva, 5(4), 220236.

19. Marchewka, A., Dąbrowski, Z., Żołądź, J.A. (2013). Fizjologia starzenia się. Profilaktyka i Rehabilitacja. Warszawa: Wyd. Naukowe PWN.

20. Mazurek, J., Szczygieł, J., Blaszkowska, A., Zgajewska, K., Richter, W., Opara, J. (2014). Aktualne zalecenia dotyczące aktywności ruchowej osób w podeszłym wieku. Gerontologia Polska, 22(2), 70-75.

21. Nowak, M., Rynkiewicz, T., Umiastowska, D. (2009). Zdrowotne uwarunkowania sprawności fizycznej kobiet w różnym wieku. W: D. Umiastowska (red.), Aktywność ruchowa ludzi w różnym wieku. T. 13. (Seria: Monografie) (s. 488-499). Szczecin: Wyd. „Albatros”.

22. Okła, W. (2006). Psychospołeczne uwarunkowania jakości życia osób starszych w rodzinach własnych i domach opieki społecznej. W: S. Steuden, M. Marczuk (red.), Starzenie się a satysfakcja z życia (s. 29-38). Lublin: Wydawnictwo KUL.

23. Osiński, W. (2013). Gerokinezjologia. Nauka i praktyka aktywności fizycznej w wieku starszym. Warszawa: Wyd. PZWL.

24. Topór-Mądry, R., Gilis-Januszewska, A., Kurkiewicz, J., Pająk, A. (2002). Szacowanie potrzeb zdrowotnych. Kraków: Wyd. Vesalius.

25. Umiastowska, D. (2012). Aktywność fizyczna i styl życia studentów Uniwersytetu Trzeciego Wieku. W: J. Nowocień, K. Zuchora (red.), Aktywność fizyczna i społeczna osób trzeciego wieku (s. 273-281). Warszawa: AWF. 